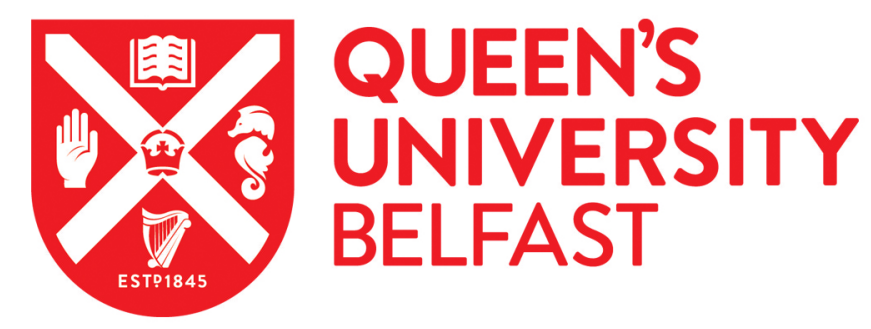

\title{
Mercury, cadmium and lead concentrations in different ecophysiological groups of earthworms in forest soils
}

Ernst, G., Zimmermann, S., Christie, P., \& Frey, B. (2008). Mercury, cadmium and lead concentrations in different ecophysiological groups of earthworms in forest soils. Environmental Pollution, 156(3), 1304-1313. https://doi.org/10.1016/j.envpol.2008.03.002

Published in:

Environmental Pollution

Queen's University Belfast - Research Portal:

Link to publication record in Queen's University Belfast Research Portal

\section{General rights}

Copyright for the publications made accessible via the Queen's University Belfast Research Portal is retained by the author(s) and / or other copyright owners and it is a condition of accessing these publications that users recognise and abide by the legal requirements associated with these rights.

Take down policy

The Research Portal is Queen's institutional repository that provides access to Queen's research output. Every effort has been made to ensure that content in the Research Portal does not infringe any person's rights, or applicable UK laws. If you discover content in the Research Portal that you believe breaches copyright or violates any law, please contact openaccess@qub.ac.uk. 


\title{
Mercury, cadmium and lead concentrations in different ecophysiological groups of earthworms in forest soils
}

\author{
Gregor Ernst ${ }^{\mathrm{a}}$, Stefan Zimmermann ${ }^{\mathrm{a}}$, Peter Christie ${ }^{\mathrm{b}}$, Beat Frey ${ }^{\mathrm{a}, *}$ \\ ${ }^{a}$ Soil Sciences, Swiss Federal Research Institute WSL, Zuercherstrasse 111, CH-8903 Birmensdorf, Switzerland \\ ${ }^{\mathrm{b}}$ Agricultural and Environmental Science Department, Queen's University Belfast, Newforge Lane, Belfast BT9 5PX, UK
}

Accumulation of non-essential heavy metals by earthworms is species-dependent and is affected by soil characteristics in natural forest soils.

\section{A R T I C L E I N F O}

Article history:

Received 2 November 2007

Received in revised form 28 January 2008

Accepted 6 March 2008

\section{Keywords:}

Earthworms

Heavy metals

$\mathrm{Pb}$

$\mathrm{Cd}$

$\mathrm{Hg}$

Bioaccumulation

Ecophysiological group

Feeding behaviour

\begin{abstract}
A B S T R A C T
Bioaccumulation of $\mathrm{Hg}, \mathrm{Cd}$ and $\mathrm{Pb}$ by eight ecophysiologically distinct earthworm species was studied in 27 polluted and uncontaminated forest soils. Lowest tissue concentrations of $\mathrm{Hg}$ and $\mathrm{Cd}$ occurred in epigeic Lumbricus rubellus and highest in endogeic Octolasion cyaneum. Soils dominated by Dendrodrilus rubidus possess a high potential of risk of $\mathrm{Pb}$ biomagnification for secondary predators. Bioconcentration factors (soil-earthworm) followed the sequence ranked $\mathrm{Cd}>\mathrm{Hg}>\mathrm{Pb}$. Ordination plots of redundancy analysis were used to compare HM concentrations in earthworm tissues with soil, leaf litter and root concentrations and with soil $\mathrm{pH}$ and CEC. Different ecological categories of earthworms are exposed to $\mathrm{Hg}, \mathrm{Cd}$ and $\mathrm{Pb}$ in the topsoil by atmospheric deposition and accumulate them in their bodies. Species differences in HM concentrations largely reflect differences in food selectivity and niche separation.
\end{abstract}

(c) 2008 Elsevier Ltd. All rights reserved.

\section{Introduction}

Natural and pristine ecosystems such as forests receive considerable inputs of heavy metals (HM) through atmospheric deposition (Mason et al., 2000; Schwesig and Matzner, 2000). Mercury $(\mathrm{Hg})$, cadmium $(\mathrm{Cd})$ and lead $(\mathrm{Pb})$ are of particular concern because they have no known biological function, are toxic to living organisms and pose a risk for human and environmental health (UNECE, Aarhus Protocol, 1998). Accumulation of these HM in forest ecosystems is influenced by the filtering effect as the canopies have a high capacity to intercept aerosols which are either washed down by rain or reach the soil through litterfall (Driscoll et al., 2007; Ettler et al., 2005). This explains why forests are often found to contain high HM concentrations in their topsoils where most of the soil animals also live. A considerable fraction is released and redistributed in the soil profile through physical and biogeochemical migration processes such as bioturbation (Dahmani-Muller et al., 2000; Klaminder et al., 2005;

\footnotetext{
* Corresponding author. Tel.: +41 447392 541; fax: +41 447392215 .

E-mail address: beat.frey@wsl.ch (B. Frey).
}

Steinnes et al., 2005). Thus, the growing burden of HM to soils and its implication for sustaining soil functioning are of immediate concern (De Vries et al., 2002).

Earthworms constitute up to $80 \%$ of the total biomass of the soil fauna and play an important role as decomposers, especially in forest ecosystems and in chemical element transformations (Ireland, 1983; Lee, 1985). Earthworms have a demonstrated ability to efficiently accumulate HM from soils (see review by Nahmani et al., 2007). As a result of their ecological importance, earthworms are good candidates for key indicator species with regard to toxic levels of pollutants in soils (Spurgeon et al., 2003). Earthworms are well known to be selective consumers (Curry and Schmidt, 2007; Neilson and Boag, 2003). Different ecological categories of earthworms ingest the various biological soil fractions, namely litter, microorganisms, humus, most mineral fractions (clay, silt, fine sand) and possibly fine living roots. Because forest soils and organic materials within them accumulate HM, they all constitute relevant food sources and therefore a potential uptake route for HM in earthworms (Abdul Rida and Bouché, 1997).

Knowledge of the heavy metal concentrations in the different ecological categories of earthworms is very important for ecological risk assessment because HM in earthworms pose serious risks of 
secondary poisoning of vertebrate predators due to biomagnification (Carpené et al., 2006; Klok et al., 2006; Ma and Talmage, 2001). Most of the available bioaccumulation data for different earthworms species are on $\mathrm{As}, \mathrm{Cd}, \mathrm{Cu}, \mathrm{Pb}$ and $\mathrm{Zn}$ (Beyer et al., 1987; Dai et al., 2004; Langdon et al., 2001; Lukkari et al., 2004; Ma, 1982; Morgan and Morgan, 1998) and very few studies have documented $\mathrm{Hg}$ concentrations in earthworm tissues (Burton et al., 2006; Ernst and Frey, 2007). These case studies have all been carried out in contaminated sites (metalliferous mine soils or regions near smelters) where relatively high metal concentrations have been considered or in laboratory experiments for short time periods with artificially spiked soil. Some data exist on $\mathrm{Cd}$ and $\mathrm{Pb}$ uptake by earthworms inhabitating "natural" forest ecosystems (Rozen, 2006; Terhivuo et al., 1994) but studies on Hg uptake by earthworms in natural conditions are lacking despite growing concern about the potential adverse effects of elevated $\mathrm{Hg}$ concentrations in the environment (Driscoll et al., 2007).

Here we consider species-specific differences in HM accumulation under natural field conditions in forest soils. Based on the ecological importance of earthworms and the limited mobility of $\mathrm{HM}$ in the soil, HM tissue concentrations in different ecological categories of earthworms may provide important information for assessing environmental risks of $\mathrm{Hg}, \mathrm{Cd}$ and $\mathrm{Pb}$ in forest ecosystems (De Vries et al., 2002). Species-specific burrowing and feeding behaviour patterns may increase the exposure of some earthworm species to HM in soils and might affect bioaccumulation. However, as far as we are aware there have been no studies exploring the importance of contrasting feeding behaviours of different ecophysiological groups of earthworm species on the accumulation of $\mathrm{Hg}$ together with $\mathrm{Cd}$ and $\mathrm{Pb}$ under natural field conditions in forest soils.

The aims of this study were to (1) determine $\mathrm{Hg}, \mathrm{Cd}$ and $\mathrm{Pb}$ tissue concentrations in ecophysiologically different earthworm species of several forest soils varying in physico-chemical properties such as $\mathrm{pH}$ and CEC, (2) determine $\mathrm{Hg}, \mathrm{Cd}$ and $\mathrm{Pb}$ concentrations in the most relevant food sources such as soil $\left(\mathrm{HNO}_{3}{ }^{-}\right.$and Lakanen-extractable heavy metals), above-ground litter and roots, and (3) assess the most relevant factors determining HM concentrations in the different ecophysiological categories of earthworms.

\section{Materials and methods}

\subsection{Site description}

Twenty-seven different forest soils differing in physico-chemical characteristics were used to estimate the most relevant heavy metal pools (soil, above-ground litter and roots) as uptake routes for earthworms. The range of $\mathrm{pH}$ values, CEC and base saturation covered by the samples from the selected soils is representative of the entire collective of forest soils within the systematic $8 \times 8 \mathrm{~km}$ grid of 173 well characterized forest sites in Switzerland (Blaser et al., 2005; Walthert et al., 2004; Zimmermann et al., 2006). With respect to bedrock material, all important lithostratigraphical units in Switzerland were represented (Blaser et al., 2000). Twentyfive sites were natural forest sites representing all geographic regions with four sites located in the Jura, seven on the Swiss Plateau, four in the Prealps, two in the Alps, and eight in southern Switzerland (Fig. 1). Two additional contaminated forest sites (site 5: vicinity of a smelter and site 6: shooting range) from the Swiss Plateau were also selected (Table 1 ).

\subsection{Sample collection}

Earthworms were collected in quadruplicate $0.25-\mathrm{m}^{2}$ plots (at least three individuals per species in each plot) by combining the methods of handsorting (Edwards and Lofty, 1977) and extraction with 0.37\% formaldehyde solution (Raw, 1959) in spring 2005. In each area the plots were randomly chosen in similar habitats (e.g., vegetation, soil type) aiming at minimizing environmental differences between sampling plots. There was a distance of about 8-12 m between adjacent plots. Earthworms were collected, washed with deionised water to remove formaldehyde and adhering soil particles and taken to the laboratory for identification and metal analysis. Before identification (Sims and Gerard, 1985), adult individuals were starved on moistened filter papers for 3 days at $15^{\circ} \mathrm{C}$ until their gut contents were completely egested. Earthworms were then frozen in liquid nitrogen, freezedried and ground to a fine powder using a swing mill (Retsch).

Soil, root and above-ground litter samples were also collected from the same sampling points. Soil and root samples were taken from A-horizons (Oh-layer not present or very small) except for the sites at Alptal (site 16), Etzwil (site 12) and Krauchtal (site 14) where samples were taken from the Oh-horizons $(+5 \mathrm{~cm})$, representing the most important habitat occupied by all earthworm groups on these sites. Concentrations of HM in earthworms and roots were related to parameter values for the depth at which the earthworms were expected to occur (Emmerling et al., 1997; van Vliet et al., 2005). Soil samples were sieved ( $2 \mathrm{~mm}$ ) in order to remove stones and pieces of litter, dried at $15^{\circ} \mathrm{C}$ in a forced-draught oven for 5 days to avoid loss of $\mathrm{Hg}$ and then gently crushed in an acid-washed porcelain pestle and mortar. Residual moisture contents of the soils were then measured $\left(105^{\circ} \mathrm{C}\right.$ for 3 days). Root samples were collected from topsoil around the tree species, which dominated at the forest site. Fresh roots were washed in deionised water to remove adhering soil particles. For the sampling of above-ground litter only the fresh needle or leaf litter of the dominant tree species were considered. All samples (roots and above-ground litter) were dried at $18{ }^{\circ} \mathrm{C}$ (residual moisture contents were subsequently measured) and were ground to a fine powder using a swing mill (Retsch).

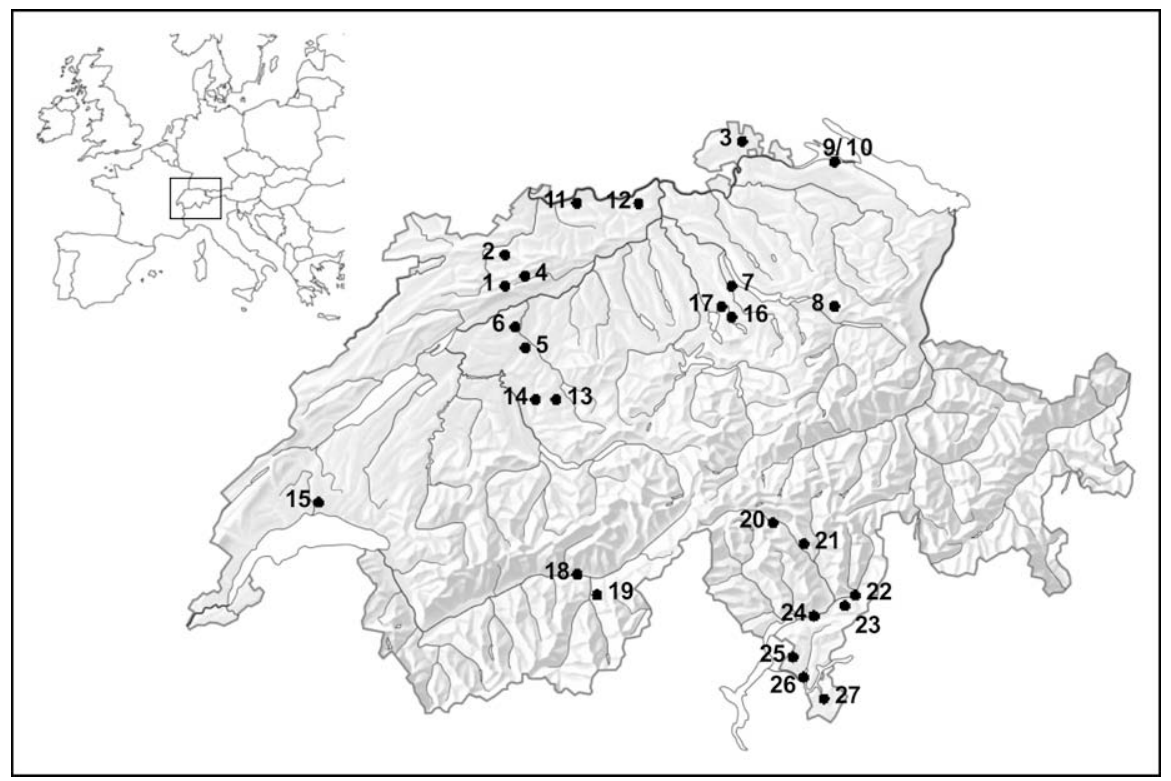

Fig. 1. Location of the forest sites studied. Their exact location and characteristic properties are presented in Table 1. 
Table 1

Location, soil type, humus form, dominating tree species, occurring earthworm species and soil properties (A horizon) in the study sites shown in Fig. 1

\begin{tabular}{|c|c|c|c|c|c|c|c|c|c|c|c|c|c|c|}
\hline No. & Forest site & $\begin{array}{l}\text { Longitude } \\
\left({ }^{\circ} \mathrm{E}\right)\end{array}$ & $\begin{array}{l}\text { Latitude } \\
\left({ }^{\circ} \mathrm{N}\right)\end{array}$ & Soil type & Humus form ${ }^{a}$ & $\begin{array}{l}\text { Dominating tree } \\
\text { species }\end{array}$ & $\begin{array}{l}\text { Earthworm } \\
\text { species }^{\text {b }}\end{array}$ & $\begin{array}{l}\text { Clay } \\
(\%)\end{array}$ & $\begin{array}{l}\text { Silt } \\
(\%)\end{array}$ & $\begin{array}{l}\text { Sand } \\
(\%)\end{array}$ & $\mathrm{pH}$ & CEC & $\begin{array}{l}\text { Corg } \\
(\%)\end{array}$ & $\mathrm{C} / \mathrm{N}$ \\
\hline 1 & Bettlachstock & $7^{\circ} 25^{\prime} 06^{\prime \prime}$ & $47^{\circ} 13^{\prime} 25^{\prime \prime}$ & Eutri-vertic Cambisol & Rhizomull & Fagus sylvatica & 4,6 & 48 & 30 & 22 & 6.5 & 458 & 12.2 & 12.2 \\
\hline 2 & Laufen & $7^{\circ} 25^{\prime} 35^{\prime \prime}$ & $47^{\circ} 23^{\prime} 28^{\prime \prime}$ & Rendzic Leptosol & Vermimull & Quercus petraea & $1,6,8$ & 43 & 22 & 35 & 7.0 & 600 & 24.6 & 18.0 \\
\hline 3 & Neunkirch & $8^{\circ} 32^{\prime} 02^{\prime \prime}$ & $47^{\circ} 41^{\prime} 10^{\prime \prime}$ & Rendzic Leptosol & Rhizomull & Fagus sylvatica & $2,3,6$ & 53 & 17 & 30 & 7.2 & 566 & 11.9 & 14.8 \\
\hline 4 & Geissgrat & $7^{\circ} 29^{\prime} 05^{\prime \prime}$ & $47^{\circ} 14^{\prime} 48^{\prime \prime}$ & Rendzic Leptosol & Mullmoder & Fagus sylvatica & $1,3,6$ & 27 & 23 & 40 & 7.0 & 788 & 14.9 & 17.1 \\
\hline 5 & Gerlafingen & $7^{\circ} 33^{\prime} 28^{\prime \prime}$ & $47^{\circ} 10^{\prime} 27^{\prime \prime}$ & Stagnic Cambisol & Rhizomull & Fagus sylvatica & $1,2,3,7$ & 21 & 46 & 33 & 4.6 & 106 & 4.1 & 14.4 \\
\hline 6 & Zuchwil & $7^{\circ} 34^{\prime} 40^{\prime \prime}$ & $47^{\circ} 11^{\prime} 45^{\prime \prime}$ & Eutric Cambisol & Rhizomull & Fagus sylvatica & $1,7,8$ & 17 & 53 & 30 & 4.5 & 141 & 3.6 & 13.5 \\
\hline 7 & Sihlwald & $8^{\circ} 34^{\prime} 06^{\prime \prime}$ & $47^{\circ} 14^{\prime} 51^{\prime \prime}$ & Gleyic Cambisol & Mullmoder & Fraxinus excelsior & 6,8 & 52 & 33 & 15 & 6.8 & 297 & 4.4 & 12.0 \\
\hline 8 & Schänis & $9^{\circ} 04^{\prime} 04^{\prime \prime}$ & $47^{\circ} 09^{\prime} 51^{\prime \prime}$ & Eutric Cambisol & Vermimull & Fagus sylvatica & $1,3,5,6,8$ & 23 & 36 & 41 & 5.0 & 121 & 3.2 & 11.3 \\
\hline 9 & Ermatingen 1 & $9^{\circ} 05^{\prime} 05^{\prime \prime}$ & $47^{\circ} 38^{\prime} 41^{\prime \prime}$ & Gleysol & Rhizomull & Acer platanoides & $1,3,5$ & 44 & 26 & 30 & 7.1 & 416 & 4.4 & 10.0 \\
\hline 10 & Ermatingen 2 & $9^{\circ} 05^{\prime} 08^{\prime \prime}$ & $47^{\circ} 38^{\prime} 45^{\prime \prime}$ & Luvic Arenosol & Leptomoder & Picea abies & $2,5,8$ & 13 & 29 & 58 & 3.4 & 280 & 4.2 & 22.1 \\
\hline 11 & Möhlin & $7^{\circ} 52^{\prime} 48^{\prime \prime}$ & $47^{\circ} 34^{\prime} 29^{\prime \prime}$ & Albic Luvisol & Rhizomull & Fagus sylvatica & 1,4 & 15 & 65 & 20 & 3.3 & 83 & 2.9 & 15.8 \\
\hline 12 & Etzwil & $8^{\circ} 11^{\prime} 27^{\prime \prime}$ & $47^{\circ} 34^{\prime} 02^{\prime \prime}$ & Albic Luvisol & Hemimor & Picea abies & 1 & 14 & 56 & 30 & 3.0 & 146 & 4.7 & 19.9 \\
\hline 13 & Burgdorf & $7^{\circ} 35^{\prime} 49^{\prime \prime}$ & $47^{\circ} 02^{\prime} 16^{\prime \prime}$ & Stagnic Umbrisol & Rhizomull & Fagus sylvatica & 4,8 & 12 & 23 & 65 & 4.1 & 58 & 2.1 & 14.3 \\
\hline 14 & Krauchtal & $7^{\circ} 34^{\prime} 11^{\prime \prime}$ & $47^{\circ} 01^{\prime} 52^{\prime \prime}$ & Stagnic Podzol & Hemimor & Picea abies & 1,7 & 4 & 25 & 71 & 3.0 & 390 & 3.3 & 23.1 \\
\hline 15 & Lausanne & $6^{\circ} 39^{\prime} 28^{\prime \prime}$ & $46^{\circ} 34^{\prime} 54^{\prime \prime}$ & Eutric Cambisol & Leptomoder & Fagus sylvatica & 1 & 13 & 25 & 62 & 3.9 & 77 & 3.5 & 15.1 \\
\hline 16 & Alptal & $8^{\circ} 42^{\prime} 39^{\prime \prime}$ & $47^{\circ} 02^{\prime} 57^{\prime \prime}$ & Umbric Gleysol & Leptomoder & Abies alba & $1,4,5,6$ & 21 & 23 & 56 & 3.4 & 258 & 14.6 & 20.0 \\
\hline 17 & Gottschalkenberg & $8^{\circ} 40^{\prime} 13^{\prime \prime}$ & $47^{\circ} 08^{\prime} 58^{\prime \prime}$ & Umbric Gleysol & Leptomoder & Abies alba & $1,5,6$ & 41 & 39 & 20 & 4.3 & 128 & 7.8 & 12.0 \\
\hline 18 & Visp & $7^{\circ} 51^{\prime} 27^{\prime \prime}$ & $46^{\circ} 17^{\prime} 52^{\prime \prime}$ & Eutric Cambisol & Mullmoder & Pinus sylvestris & $4,5,7$ & 14 & 52 & 34 & 5.5 & 263 & 11.7 & 17.2 \\
\hline 19 & Stalden & $7 \circ 52^{\prime} 47^{\prime \prime}$ & $46^{\circ} 14^{\prime} 24^{\prime \prime}$ & Leptic Cambisol & Mullmoder & Pinus sylvestris & 5 & 11 & 35 & 54 & 7.1 & 225 & 4.8 & 17.6 \\
\hline 20 & Piotta & $8^{\circ} 40^{\prime} 23^{\prime \prime}$ & $46^{\circ} 30^{\prime} 44^{\prime \prime}$ & Eutric Cambisol & Leptomoder & Picea abies & 1,6 & 9 & 25 & 66 & 4.6 & 130 & 8.2 & 15.4 \\
\hline 21 & Bodio & $8^{\circ} 55^{\prime} 39^{\prime \prime}$ & $46^{\circ} 22^{\prime} 51^{\prime \prime}$ & Podzol & Rhizomull & Castanea sativa & 2 & 7 & 17 & 76 & 3.7 & 104 & 10.9 & 20.0 \\
\hline 22 & Pian $d^{\prime}$ Arf & $9^{\circ} 07^{\prime} 41^{\prime \prime}$ & $46^{\circ} 13^{\prime} 34^{\prime \prime}$ & Albic Umbrisol & Rhizomull & Castanea sativa & 1,2 & 10 & 22 & 68 & 3.8 & 69 & 9.1 & 20.6 \\
\hline 23 & Laura & $9^{\circ} 06^{\prime} 31^{\prime \prime}$ & $46^{\circ} 12^{\prime} 46^{\prime \prime}$ & Eutric Cambisol & Leptomoder & Picea abies & 1 & 10 & 23 & 67 & 4.0 & 111 & 11.2 & 17.9 \\
\hline 24 & Copera & $8^{\circ} 59^{\prime} 22^{\prime \prime}$ & $46^{\circ} 08^{\prime} 58^{\prime \prime}$ & Albic Umbrisol & Mullmoder & Castanea sativa & 2 & 17 & 25 & 58 & 3.6 & 139 & 11.0 & 16.7 \\
\hline 25 & Novaggio & $8^{\circ} 50^{\prime} 05^{\prime \prime}$ & $46^{\circ} 01^{\prime} 27^{\prime \prime}$ & Eutric Cambisol & Leptomoder & Quercus cerris & 2 & 14 & 18 & 68 & 3.8 & 84 & 10.6 & 17.9 \\
\hline 26 & Morcote & $8^{\circ} 54^{\prime} 30^{\prime \prime}$ & $45^{\circ} 56^{\prime} 39^{\prime \prime}$ & Eutric Cambisol & Mullmoder & Castanea sativa & 2 & 19 & 44 & 37 & 3.5 & 143 & 10.6 & 23.8 \\
\hline 27 & Sagno Caneggio & $9^{\circ} 02^{\prime} 02^{\prime \prime}$ & $45^{\circ} 51^{\prime} 46^{\prime \prime}$ & Eutric Cambisol & Leptomoder & Castanea sativa & 1 & 9 & 35 & 56 & 3.4 & 114 & 9.6 & 19.0 \\
\hline
\end{tabular}

${ }^{\text {a }}$ Humus forms according to Green et al. (1993).

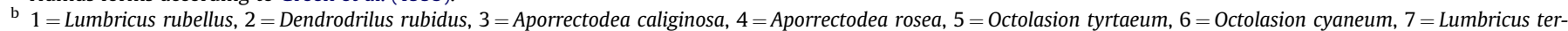
restris, $8=$ Aporrectodea longa.

\subsection{Analysis of heavy metals and soil properties}

Soil $\mathrm{pH}$ was measured potentiometrically in $0.01 \mathrm{M} \mathrm{CaCl}_{2}$ with a soil-extractant ratio of $1: 2$. Exchangeable cations were extracted using $1 \mathrm{M} \mathrm{NH}_{4} \mathrm{Cl}$ for $1 \mathrm{~h}$ on an endover-end shaker with a solid-extractant ratio of $1: 10$. The extracted cations were measured by inductively coupled plasma atomic emission spectrometry (ICP-AES, Perkin-Elmer OPTIMA 3000). The effective cation exchange capacity (CEC) was calculated by summing up the molar charge concentrations of exchangeable $\mathrm{Na}, \mathrm{K}$, $\mathrm{Ca}, \mathrm{Mg}, \mathrm{Mn}, \mathrm{Al}$, and Fe. Base saturation (BS) was defined as the sum of the molar charge concentrations of $\mathrm{Na}, \mathrm{K}, \mathrm{Ca}$ and $\mathrm{Mg}$ as a percentage of $\mathrm{CEC}$. Loss on ignition (LOI) was determined by igniting the dry soil for $2 \mathrm{~h}$ at $750{ }^{\circ} \mathrm{C}$. Total $\mathrm{C}$ and total $\mathrm{N}$ were measured with a CN analyzer (NA 2500, CE Instruments).

"Pseudo-total" HM concentrations in soils were determined by extracting $2.5 \mathrm{~g}$ of dried soil in $25 \mathrm{ml}$ of $2 \mathrm{M} \mathrm{HNO}_{3}$ for $2 \mathrm{~h}$ at $95^{\circ} \mathrm{C}(100 \mathrm{rpm})(\mathrm{Hu}$ and Häni, 1983). The total mobilizable heavy metal pools were determined in Lakanen extracts according to Lakanen and Ervio (1971). Here, $5 \mathrm{~g}$ of soil were extracted in $50 \mathrm{ml}$ of ammonium acetate-EDTA (ammonium acetate: 0.5 M; EDTA: $0.02 \mathrm{M}$; $\mathrm{pH}=4.65$ ) for $1 \mathrm{~h}$ at $20^{\circ} \mathrm{C}$ by end-over-end shaking. All soil extracts were filtered through Schleicher \& Schuell No. $790 \frac{1}{2}$ filter papers. The biological samples (litter, roots and earthworms) were solubilized with a microwave digestion system (MLS Milestone, Perkin-Elmer) in $\mathrm{HNO}_{3}(65 \%)$ and $\mathrm{HF}(40 \%)$. After filtering, all extracts were analysed by inductively coupled plasma-mass spectrometry (ICP-MS: ELAN 6000, Perkin-Elmer) for Pb and Cd or by cold vapour atomic absorption spectroscopy (CV-AAS: 2000, Perkin-Elmer) for $\mathrm{Hg}$, with detection limits of about $0.02 \mathrm{mg} \mathrm{kg}^{-1} \mathrm{dw}$ for $\mathrm{Pb}, 0.01 \mathrm{mg} \mathrm{kg}^{-1} \mathrm{dw}$ for $\mathrm{Cd}$ and $0.005 \mathrm{mg} \mathrm{kg}^{-1} \mathrm{dw}$ for $\mathrm{Hg}$. Accuracy and analytical precision were checked against certified reference materials (NIST1547 Peach Leaves certified value: $0.031 \mathrm{mg} \mathrm{kg}^{-1} \mathrm{Hg}, 0.026 \mathrm{mg} \mathrm{kg}^{-1} \mathrm{Cd}, 0.87 \mathrm{mg} \mathrm{kg}^{-1} \mathrm{~Pb} / \mathrm{CMI} 7004$ Soil Loam certified value: $0.223 \mathrm{mg} \mathrm{kg}^{-1} \mathrm{Hg}, 1.52 \mathrm{mg} \mathrm{kg}^{-1} \mathrm{Cd}, 93.4 \mathrm{mg} \mathrm{kg}^{-1} \mathrm{~Pb}$ ) and regular analysis does not exceed $15 \%$ for any of the reported metals.

\subsection{Statistics}

Data are presented as means and/or medians with standard deviations calculated using the Origin version 7 software package (Origin Lab Corporation) and Excel (Microsoft Corporation). Data were log-transformed to assure normality and verified using the Shapiro-Wilk normality test (Origin version 7; Origin Lab Corporation). Mean values were compared by Student's $t$-test (or by the Wilcoxon test in the case of data not normally distributed) at the $5 \%$ significance level using Origin version 7 (Origin Lab Corporation). Concentration factors were calculated by dividing the total concentrations in earthworms or roots by the $\mathrm{HNO}_{3}$-extractable $\mathrm{HM}$ concentrations in soils (Ernst and Frey, 2007).
Relationships between heavy metal concentrations in earthworms and chemical soil properties were determined by multivariate analysis using the Canoco version 4.5 software package (Biometris, Plant Research International). Detrended canonical correspondence analysis' (DCCA) indicated the use of redundancy analysis (RDA) because of predominantly linear relationships within all data (Ter Braak and Smilauer, 2002). Significance of the first and of all ordinations axes was calculated by the Monte-Carlo significance test. In the ordination diagrams the cosines of angles between arrows of the chemical soil parameters and earthworm tissue concentrations are predicted to be the approximated correlation coefficients (Leps and Smilauer, 2003; Ter Braak and Smilauer, 2002).

\section{Results}

\subsection{General soil characteristics and heavy metal concentrations in forest soils}

In Table 1 the most important soil properties are given for the forest sites at which earthworms have been found for assessment of accumulated metals. Across all the soils studied the $\mathrm{pH}$ ranged between 3.0 and 7.2 (median 4.11) and the CEC between 58 and $788 \mathrm{mmol}_{\mathrm{C}} \mathrm{kg}^{-1}$ (median $143 \mathrm{mmol}_{\mathrm{C}} \mathrm{kg}^{-1}$ soil). The lowest Corg content was 2.1\% (site 13: Burgdorf) and the highest 24.6\% (site 2: Laufen) and $\mathrm{C} / \mathrm{N}$ ratio ranged between 10.0 and 23.8 in the different forest soils (Table 1 ). The $\mathrm{HNO}_{3}$-extractable $\mathrm{Pb}$ concentrations in the soils (including the contaminated sites 5 and 6: Gerlafingen and Zuchwil) were between 10 and $6639 \mathrm{mg} \mathrm{Pb} \mathrm{kg}^{-1}$ with a median of $45.1 \mathrm{mg} \mathrm{Pb} \mathrm{kg}^{-1}$ soil (Table 2) but Lakanen-extractable Pb concentrations were always lower than the $\mathrm{HNO}_{3}$-extractable $\mathrm{Pb}$ concentrations. The $\mathrm{Pb}$ concentrations were lowest in above-ground litter, ranging from 0.9 to $31.4 \mathrm{mg} \mathrm{kg}^{-1} \mathrm{dw}$, but when the soils from Gerlafingen and Zuchwil were included the $\mathrm{Pb}$ concentrations reached up to $278.5 \mathrm{mg} \mathrm{Pb} \mathrm{kg}^{-1}$ with a median of $5.3 \mathrm{mg} \mathrm{Pb} \mathrm{kg}^{-1}$ $\mathrm{dw}$ (Table 2). The $\mathrm{HNO}_{3}$-extractable $\mathrm{Cd}$ concentrations in the forest soils ranged from 0.09 (site 11: Möhlin) to $3.28 \mathrm{mg} \mathrm{Cd} \mathrm{kg}^{-1}$ soil (Gerlafingen), with a median of $0.31 \mathrm{mg} \mathrm{kg}^{-1}$ soil. The largest Cd value in the above-ground litter was detected in the contaminated 
Table 2

Means and standard deviations of the $\mathrm{HNO}_{3}$-extractable $\mathrm{HM}$ concentrations in soils, above-ground litter, roots $\left(\mathrm{mg} \mathrm{kg}^{-1} \mathrm{dw}\right)$ and concentrations in Lakanen extracts of soils (mg kg $\left.{ }^{-1}\right)$ on selected sites $(n=4)$

\begin{tabular}{|c|c|c|c|c|c|c|c|c|c|c|c|c|}
\hline \multirow[t]{2}{*}{ No. } & \multicolumn{3}{|c|}{ HNO3-extractable HM concentrations in soils } & \multicolumn{3}{|c|}{ Lakanen-extractable HM concentrations in soils } & \multicolumn{3}{|c|}{$\begin{array}{l}\text { Total HM concentrations } \\
\text { in above-ground litter }\end{array}$} & \multicolumn{3}{|c|}{$\begin{array}{l}\text { Total HM concentrations } \\
\text { in root litter }\end{array}$} \\
\hline & $\mathrm{Pb}$ & $\mathrm{Cd}$ & $\mathrm{Hg}$ & $\mathrm{Pb}$ & $\mathrm{Cd}$ & $\mathrm{Hg}$ & $\mathrm{Pb}$ & $\mathrm{Cd}$ & $\mathrm{Hg}$ & $\mathrm{Pb}$ & $\mathrm{Cd}$ & $\mathrm{Hg}$ \\
\hline 1 & $39.2 \pm 7.0$ & $1.23 \pm 0.07$ & $0.183 \pm 0.035$ & $16.7 \pm 2.3$ & $0.75 \pm 1020.9$ & n.d. ${ }^{a}$ & $3.7 \pm 0.92$ & $0.18 \pm 0.01$ & $0.108 \pm 0.020$ & $15.8 \pm 2.0$ & $0.86 \pm 0.01$ & $0.143 \pm 0.017$ \\
\hline 2 & $34.4 \pm 3.4$ & $1.77 \pm 0.13$ & $0.114 \pm 0.013$ & $21.6 \pm 2.8$ & $0.86 \pm 0.07$ & n.d. & $2.7 \pm 1.0$ & $0.23 \pm 0.04$ & $0.025 \pm 0.005$ & $17.9 \pm 2.8$ & $1.20 \pm 0.21$ & $0.072 \pm 0.017$ \\
\hline 3 & $35.4 \pm 6.6$ & $1.20 \pm 0.13$ & $0.233 \pm 0.025$ & $23.1 \pm 1.6$ & $0.78 \pm 0.11$ & n.d. & $1.7 \pm 0.5$ & $0.11 \pm 0.05$ & $0.012 \pm 0.005$ & $5.5 \pm 0.9$ & $0.30 \pm 0.05$ & $0.005 \pm 0.002$ \\
\hline 4 & $113.1 \pm 12.5$ & $1.91 \pm 0.23$ & $0.466 \pm 0.067$ & $80.1 \pm 9.0$ & $1.26 \pm 0.10$ & n.d. & $22.6 \pm 8.1$ & $0.48 \pm 0.08$ & $0.224 \pm 0.054$ & $18.8 \pm 3.0$ & $1.15 \pm 0.18$ & $0.114 \pm 0.034$ \\
\hline 5 & $1421.7 \pm 1311.6$ & $3.28 \pm 0.25$ & $0.197 \pm 0.025$ & $917.3 \pm 1020.9$ & $1.17 \pm 0.17$ & $0.010 \pm 0.003$ & $82.4 \pm 88.5$ & $1.53 \pm 0.13$ & $0.133 \pm 0.023$ & $122.9 \pm 147.2$ & $2.71 \pm 0.17$ & $0.390 \pm 0.084$ \\
\hline 6 & $6639.4 \pm 515.3$ & $0.31 \pm 0.03$ & $0.191 \pm 0.019$ & $4567.5 \pm 194.9$ & $0.21 \pm 0.02$ & n.d. & $278.5 \pm 25.1$ & $0.27 \pm 0.02$ & $0.101 \pm 0.037$ & $284.6 \pm 122.3$ & $0.78 \pm 0.09$ & $0.131 \pm 0.033$ \\
\hline 7 & $30.9 \pm 5.0$ & $0.24 \pm 0.03$ & $0.128 \pm 0.030$ & $13.6 \pm 4.3$ & $0.15 \pm 0.02$ & n.d. & $6.1 \pm 1.7$ & $0.21 \pm 0.03$ & $0.116 \pm 0.014$ & $17.7 \pm 5.2$ & $1.21 \pm 0.21$ & $0.166 \pm 0.013$ \\
\hline 8 & $32.0 \pm 4.0$ & $0.49 \pm 0.11$ & $0.323 \pm 0.015$ & $14.4 \pm 2.6$ & $0.31 \pm 0.05$ & n.d. & $0.9 \pm 0.3$ & $0.12 \pm 0.03$ & $0.007 \pm 0.002$ & $53.9 \pm 5.7$ & $1.00 \pm 0.09$ & $0.174 \pm 0.016$ \\
\hline 9 & $35.0 \pm 5.9$ & $0.44 \pm 0.07$ & $0.157 \pm 0.031$ & $12.8 \pm 4.0$ & $0.35 \pm 0.04$ & n.d. & $3.5 \pm 1.0$ & $0.10 \pm 0.01$ & $0.081 \pm 0.010$ & $14.60 \pm 2.2$ & $0.84 \pm 0.05$ & $0.091 \pm 0.035$ \\
\hline 10 & $25.0 \pm 3.2$ & $0.20 \pm 0.02$ & $0.132 \pm 0.016$ & $15.4 \pm 1.3$ & $0.19 \pm 0.07$ & n.d. & $22.0 \pm 9.0$ & $0.51 \pm 0.18$ & $0.185 \pm 0.023$ & $12.7 \pm 4.1$ & $1.32 \pm 0.07$ & $0.140 \pm 0.016$ \\
\hline 11 & $31.4 \pm 5.4$ & $0.09 \pm 0.01$ & $0.143 \pm 0.035$ & $22.1 \pm 3.3$ & $0.06 \pm 0.03$ & $0.003 \pm 0.001$ & $7.3 \pm 2.3$ & $0.33 \pm 0.07$ & $0.115 \pm 0.040$ & $89.5 \pm 22.5$ & $0.69 \pm 0.05$ & $0.260 \pm 0.022$ \\
\hline 12 & $54.6 \pm 3.5$ & $0.17 \pm 0.03$ & $0.333 \pm 0.060$ & $41.0 \pm 2.7$ & $0.15 \pm 0.04$ & $0.006 \pm 0.001$ & $4.5 \pm 0.6$ & $0.35 \pm 0.09$ & $0.006 \pm 0.003$ & $52.3 \pm 8.8$ & $1.52 \pm 0.13$ & $0.202 \pm 0.029$ \\
\hline 13 & $10.2 \pm 5.3$ & $0.10 \pm 0.01$ & $0.046 \pm 0.006$ & $3.8 \pm 0.7$ & $0.07 \pm 0.03$ & n.d. & $2.4 \pm 0.5$ & $0.09 \pm 0.01$ & $0.057 \pm 0.013$ & $3.3 \pm 1.3$ & $0.31 \pm 0.01$ & $0.067 \pm 0.010$ \\
\hline 14 & $45.1 \pm 5.8$ & $0.11 \pm 0.04$ & $0.308 \pm 0.013$ & $38.4 \pm 2.6$ & $0.08 \pm 0.01$ & $0.003 \pm 0.001$ & $14.4 \pm 3.2$ & $0.51 \pm 0.09$ & $0.213 \pm 0.037$ & $40.4 \pm 1.4$ & $0.55 \pm 0.07$ & $0.196 \pm 0.061$ \\
\hline 15 & $21.2 \pm 2.6$ & $0.14 \pm 0.02$ & $0.077 \pm 0.023$ & $6.4 \pm 1.5$ & $0.05 \pm 0.02$ & n.d. & $5.9 \pm 1.8$ & $0.26 \pm 0.03$ & $0.102 \pm 0.038$ & $12.2 \pm 1.6$ & $0.50 \pm 0.10$ & $0.096 \pm 0.019$ \\
\hline 16 & $54.4 \pm 3.3$ & $0.62 \pm 0.09$ & $0.202 \pm 0.030$ & $24.9 \pm 2.6$ & $0.51 \pm 0.06$ & n.d. & $25.8 \pm 3.3$ & $0.43 \pm 0.02$ & $0.167 \pm 0.021$ & $35.4 \pm 8.3$ & $0.74 \pm 0.05$ & $0.007 \pm 0.001$ \\
\hline 17 & $42.0 \pm 9.0$ & $0.35 \pm 0.10$ & $0.090 \pm 0.016$ & $17.9 \pm 2.8$ & $0.24 \pm 0.07$ & n.d. & $17.4 \pm 8.9$ & $0.52 \pm 0.04$ & $0.143 \pm 0.021$ & $17.9 \pm 4.7$ & $1.71 \pm 0.24$ & $0.008 \pm 0.002$ \\
\hline 18 & $31.0 \pm 3.2$ & $0.16 \pm 0.04$ & $0.553 \pm 0.040$ & $12.7 \pm 2.9$ & $0.08 \pm 0.02$ & $0.002 \pm 0.001$ & $4.1 \pm 0.8$ & $0.09 \pm 0.02$ & $0.106 \pm 0.023$ & $23.9 \pm 2.8$ & $0.50 \pm 0.06$ & $0.258 \pm 0.016$ \\
\hline 19 & $16.1 \pm 1.2$ & $0.13 \pm 0.04$ & $0.067 \pm 0.006$ & $4.7 \pm 0.9$ & $0.08 \pm 0.03$ & n.d. & $5.3 \pm 0.5$ & $0.07 \pm 0.01$ & $0.055 \pm 0.013$ & $7.1 \pm 2.6$ & $0.14 \pm 0.01$ & $0.026 \pm 0.006$ \\
\hline 20 & $95.4 \pm 9.1$ & $0.59 \pm 0.08$ & $0.130 \pm 0.026$ & $65.8 \pm 5.8$ & $0.47 \pm 0.03$ & n.d. & $31.4 \pm 3.6$ & $0.35 \pm 0.03$ & $0.148 \pm 0.022$ & $28.0 \pm 2.6$ & $1.16 \pm 0.05$ & $0.045 \pm 0.009$ \\
\hline 21 & $89.9 \pm 10.8$ & $0.38 \pm 0.07$ & $0.137 \pm 0.030$ & $63.1 \pm 6.9$ & $0.29 \pm 0.02$ & n.d. & $2.1 \pm 0.2$ & $0.16 \pm 0.01$ & $0.006 \pm 0.002$ & $59.4 \pm 10.9$ & $0.85 \pm 0.01$ & $0.006 \pm 0.001$ \\
\hline 22 & $56.6 \pm 2.3$ & $0.27 \pm 0.02$ & $0.174 \pm 0.025$ & $44.4 \pm 3.4$ & $0.18 \pm 0.02$ & n.d. & $3.5 \pm 1.3$ & $0.16 \pm 0.03$ & $0.061 \pm 0.010$ & $21.8 \pm 5.7$ & $0.83 \pm 0.10$ & $0.067 \pm 0.016$ \\
\hline 23 & $46.9 \pm 9.5$ & $0.18 \pm 0.02$ & $0.159 \pm 0.036$ & $28.0 \pm 3.2$ & $0.11 \pm 0.02$ & n.d. & $18.6 \pm 4.0$ & $0.20 \pm 0.03$ & $0.199 \pm 0.035$ & $20.6 \pm 1.6$ & $1.66 \pm 0.07$ & $0.075 \pm 0.014$ \\
\hline 24 & $64.7 \pm 9.1$ & $0.39 \pm 0.11$ & $0.217 \pm 0.030$ & $41.0 \pm 6.5$ & $0.24 \pm 0.03$ & n.d. & $19.9 \pm 3.9$ & $0.23 \pm 0.02$ & $0.098 \pm 0.039$ & $39.3 \pm 3.1$ & $0.66 \pm 0.05$ & $0.152 \pm 0.026$ \\
\hline 25 & $63.2 \pm 3.9$ & $0.39 \pm 0.06$ & $0.123 \pm 0.012$ & $47.6 \pm 11.6$ & $0.26 \pm 0.04$ & n.d. & $3.3 \pm 1.1$ & $0.12 \pm 0.06$ & $0.007 \pm 0.002$ & $44.0 \pm 4.7$ & $0.44 \pm 0.04$ & $0.006 \pm 0.004$ \\
\hline 26 & $106.5 \pm 13.6$ & $0.27 \pm 0.02$ & $0.296 \pm 0.025$ & $69.3 \pm 7.3$ & $0.17 \pm 0.05$ & n.d. & $5.1 \pm 1.7$ & $0.30 \pm 0.04$ & $0.103 \pm 0.019$ & $26.0 \pm 4.2$ & $0.64 \pm 0.07$ & $0.181 \pm 0.042$ \\
\hline 27 & $81.6 \pm 2.8$ & $0.22 \pm 0.03$ & $0.169 \pm 0.026$ & $73.2 \pm 4.4$ & $0.19 \pm 0.02$ & n.d. & $4.7 \pm 1.9$ & $0.17 \pm 0.02$ & $0.087 \pm 0.008$ & $37.0 \pm 3.7$ & $0.83 \pm 0.14$ & $0.171 \pm 0.032$ \\
\hline
\end{tabular}

n.d. = below detection limit 
Table 3

Median and range (min-max) of earthworm tissue concentrations of heavy metals in different earthworm species

\begin{tabular}{|c|c|c|c|c|c|}
\hline \multirow[t]{2}{*}{ Earthworm species } & \multirow[t]{2}{*}{ Ecophysiological group } & \multirow[t]{2}{*}{$n^{\mathrm{a}}$} & \multicolumn{3}{|c|}{ Earthworm tissue concentrations ( $\mathrm{mg} \mathrm{kg}^{-1} \mathrm{dw}$ ) } \\
\hline & & & $\mathrm{Pb}$ & $\mathrm{Cd}$ & $\mathrm{Hg}$ \\
\hline Lumbricus rubellus & Epigeic & 16 & $6.82(2.8-1615.3)$ & $7.3(2.7-15.3)$ & $0.2(0.03-0.4)$ \\
\hline Dendrodrilus rubidus & Epigeic & 8 & $425.67(8.8-668.0)$ & $10.0(6.4-44.9)$ & $0.6(0.2-2.0)$ \\
\hline Aporrectodea caliginosa & Endogeic & 5 & $12.45(1.3-122.9)$ & $9.7(0.01-22.9)$ & $0.7(0.01-2.3)$ \\
\hline Aporrectodea rosea & Endogeic & 5 & $2.13(1.1-626.7)$ & $12.5(6.4-40.7)$ & $1.8(1.0-2.5)$ \\
\hline Octolasion tyrtaeum & Endogeic & 7 & $6.68(3.3-18.8)$ & $7.3(3.4-12.6)$ & $1.1(0.3-1.9)$ \\
\hline Octolasion cyaneum & Endogeic & 9 & $14.0(1.4-189.1)$ & $17.8(7.1-58.5)$ & $1.9(0.7-4.8)$ \\
\hline Lumbricus terrestris & Anecic & 4 & $44.3(4.9-3699.2)$ & $7.4(4.1-15.2)$ & $0.4(0.2-0.5)$ \\
\hline Aporrectodea longa & Anecic & 6 & $12.0(4.5-11533.0)$ & $10.1(4.1-22.0)$ & $1.0(0.3-2.0)$ \\
\hline
\end{tabular}

${ }^{\text {a }} n=$ Number of forest sites where earthworm species were found (not all species were found in every sample plot).

site of Gerlafingen ( $1.53 \mathrm{mg} \mathrm{kg}^{-1} \mathrm{dw}$ ), whereas the median was found to be $0.23 \mathrm{mg} \mathrm{Cd} \mathrm{kg}^{-1} \mathrm{dw}$ for all sites. In general, roots contained higher $\mathrm{Cd}$ concentrations than did soils or leaf litter, reaching values between 0.30 (site 3: Neunkirch) and $2.71 \mathrm{mg} \mathrm{kg}^{-1} \mathrm{dw}$ (site 19: Stalden) with a median of $0.83 \mathrm{mg} \mathrm{kg}^{-1} \mathrm{dw}$ (Table 2). In contrast, $\mathrm{Hg}$ concentrations in soils were in general higher than in leaf litter or roots, ranging from 0.046 (site 13: Burgdorf) to $0.553 \mathrm{mg} \mathrm{kg}^{-1}$ soil (site 18: Visp) with a median of $0.169 \mathrm{mg} \mathrm{kg}^{-1}$ soil (Table 2). Lakanen-extractable $\mathrm{Hg}$ concentrations in soils were usually below the detection limit $\left(<0.001 \mathrm{mg} \mathrm{Hg} \mathrm{kg}^{-1}\right.$ soil). $\mathrm{Hg}$ concentrations tended to be higher in roots than in above-ground litter.

\section{2. $\mathrm{Hg}, \mathrm{Cd}$ and $\mathrm{Pb}$ concentrations in earthworm tissues}

HM tissue concentrations in earthworms varied among forest sites, individual heavy metals and the different ecophysiologically groups of earthworms. Tissue $\mathrm{Pb}$ concentrations in earthworms ranged from 1 to $668 \mathrm{mg} \mathrm{Pb} \mathrm{kg}^{-1} \mathrm{dw}$ in natural forest sites and the highest $\mathrm{Pb}$ concentrations were measured in Aporrectodea longa (Ude, 1885$)\left(11,533.0 \mathrm{mg} \mathrm{Pb} \mathrm{kg}^{-1} \mathrm{dw}\right)$, in Lumbricus terrestris (Linnaeus, 1758) (3699.2 $\mathrm{mg} \mathrm{Pb} \mathrm{kg}^{-1} \mathrm{dw}$ ), and in Lumbricus rubellus (Hoffmeister, 1843) (1615.3 $\mathrm{mg} \mathrm{Pb} \mathrm{kg}^{-1} \mathrm{dw}$ ) obtained from the shooting range at Zuchwil (Table 3 ). In natural forest sites lowest tissue $\mathrm{Pb}$ concentrations were measured in Aporrectodea rosea (Savigny, 1826) (median of $2.1 \mathrm{mg} \mathrm{Pb} \mathrm{kg}^{-1} \mathrm{dw}$ ) and highest in Dendrodrilus rubidus (Savigny, 1826) (median of $425.7 \mathrm{mg} \mathrm{Pb} \mathrm{kg}^{-1}$ ). The Cd concentrations in earthworm tissues were lower than those of $\mathrm{Pb}$, ranging between 0.01 and $58.5 \mathrm{mg} \mathrm{Cd} \mathrm{kg}^{-1} \mathrm{dw}$. Lowest tissue $\mathrm{Cd}$ concentrations were determined in $L$. rubellus (median of $7.3 \mathrm{mg} \mathrm{Cd} \mathrm{kg}^{-1} \mathrm{dw}$ ) and highest in Octolasion cyaneum (Savigny, 1826) (median of $17.8 \mathrm{mg} \mathrm{Cd} \mathrm{kg}^{-1} \mathrm{dw}$ ). $\mathrm{Hg}$ concentrations in earthworm tissues were between 0.01 and $4.79 \mathrm{mg} \mathrm{Hg} \mathrm{kg}^{-1} \mathrm{dw}$,

\section{Table 4}

Means and standard deviations of species-specific concentration factors (CF) soilearthworms (earthworm tissue concentrations divided by $\mathrm{HNO}_{3}$-extractable $\mathrm{HM}$ soil concentrations)

\begin{tabular}{lllll}
\hline Ecophysiological & Species & \multicolumn{3}{l}{ CF soil-earthworms } \\
\cline { 3 - 5 } group & & $\mathrm{Pb}$ & $\mathrm{Cd}$ & $\mathrm{Hg}$ \\
\hline Epigeic & Lumbricus rubellus $(n=16)$ & $0.2 \pm 0.1$ & $26.9 \pm 26.6$ & $1.1 \pm 0.6$ \\
& Dendrodrilus rubidus $(n=8)$ & $4.7 \pm 3.5$ & $37.8 \pm 43.4$ & $4.1 \pm 3.3$ \\
Endogeic & Aporrectodea caliginosa & $0.8 \pm 1.5$ & $11.2 \pm 19.6$ & $2.9 \pm 2.5$ \\
& $(n=5)$ & & & \\
& Aporrectodea rosea $(n=5)$ & $4.5 \pm 9.8$ & $120.6 \pm 179.9$ & $15.2 \pm 15.3$ \\
& Octolasion tyrtaeum $(n=7)$ & $0.3 \pm 1.5$ & $28.1 \pm 16.9$ & $7.6 \pm 4.5$ \\
& Octolasion cyaneum $(n=9)$ & $1.2 \pm 2.4$ & $47.9 \pm 70.1$ & $14.7 \pm 14.3$ \\
Anecic & Lumbricus terrestris $(n=4)$ & $0.3 \pm 0.2$ & $26.5 \pm 15.8$ & $1.5 \pm 0.8$ \\
& Aporrectodea longa $(n=6)$ & $0.7 \pm 0.5$ & $57.4 \pm 86.8$ & $10.7 \pm 11.3$ \\
\hline
\end{tabular}

with $L$. rubellus accumulating the lowest (median of $0.18 \mathrm{mg} \mathrm{Hg} \mathrm{kg}^{-1} \mathrm{dw}$ ) and 0 . cyaneum the largest (median of $\left.1.85 \mathrm{mg} \mathrm{Hg} \mathrm{kg}^{-1} \mathrm{dw}\right)$.

Concentration factors (soil-earthworms) showed high variability among earthworm species and HM. They reached values between $0.2 \pm 0.1$ (L. rubellus) and $4.7 \pm 3.5$ (D. rubidus) for $\mathrm{Pb}$, $11.2 \pm 19.6$ (Aporrectodea caliginosa, Savigny, 1826) and $120.6 \pm$ 179.9 (A. rosea) for Cd, and $1.1 \pm 0.6$ (L. rubellus) and $15.2 \pm 15.3$ ( $A$. rosea) for $\mathrm{Hg}$ (Table 4). In addition, we calculated concentration factors soil-roots, regarding sites where Fagus sylvatica (soil $\mathrm{pH}>5.5$ ) or Picea abies (soil $\mathrm{pH}<5.0$ ) dominates (data not shown). With respect to $\mathrm{Pb}$ and $\mathrm{Cd}$, we found significantly higher concentration factors for the path soil-roots $(0.65 \pm 0.231$ for $\mathrm{Pb}$ and $6.00 \pm 3.04$ for $\mathrm{Cd}$ ) on sites where P. abies dominates than on sites where F. sylvatica dominates $(0.32 \pm 0.17$ for $\mathrm{Pb}$ and $1.68 \pm 1.59$ for $\mathrm{Cd}$ ).

\subsection{Relationships between heavy metal accumulation and environmental variables}

Using redundancy analysis (RDA) we determined the soil parameters, which mostly influenced the accumulation of $\mathrm{Pb}, \mathrm{Cd}$ and $\mathrm{Hg}$ in the tissues of the different earthworm species. With regard to $\mathrm{Pb}, \mathrm{RDA}$ indicated that $97.6 \%$ of the total variance (first two ordination axes) within the tissue concentrations of earthworms was explained by soil chemical parameters, above-ground litter and roots (Table 5). High species-environment relationships pointed out a strong relationship (0.997) between $\mathrm{Pb}$ concentrations in the different food sources (soils, above-ground litter and roots) and the various ecophysiological groups of earthworms. Therefore, $\mathrm{Pb}$ concentrations in soils $\left(\mathrm{HNO}_{3}\right.$ - and Lakanen-extractable $)$ and in leaf litter were the most important parameters determining $\mathrm{Pb}$ concentrations in epigeic and anecic earthworms (Fig. 2a) but $\mathrm{Pb}$

Table 5

Results of redundancy analysis (RDA)

\begin{tabular}{|c|c|c|c|c|c|c|}
\hline \multirow[t]{2}{*}{ Axes } & \multicolumn{2}{|l|}{$\mathrm{Pb}$} & \multicolumn{2}{|l|}{$\mathrm{Cd}$} & \multicolumn{2}{|l|}{$\mathrm{Hg}$} \\
\hline & 1 & 2 & 1 & 2 & 1 & 2 \\
\hline Eigenvalues & 0.971 & 0.005 & 0.213 & 0.066 & 0.336 & 0.012 \\
\hline $\begin{array}{l}\text { Species-environment } \\
\text { correlations }\end{array}$ & 0.997 & 0.801 & 0.526 & 0.768 & 0.611 & 0.404 \\
\hline \multicolumn{7}{|l|}{$\begin{array}{l}\text { Cumulative percentage } \\
\text { variance of }\end{array}$} \\
\hline Species data & 97.1 & 97.6 & 21.3 & 27.9 & 33.6 & 34.8 \\
\hline $\begin{array}{l}\text { Species-environment } \\
\text { relation }\end{array}$ & 99.2 & 99.7 & 70.6 & 92.4 & 96.4 & 99.9 \\
\hline $\begin{array}{l}\text { Monte-Carlo significance } \\
\text { test }\end{array}$ & & All axes & & All axes & & All axes \\
\hline$F$-value & 672.16 & 153.73 & 5.418 & 1.908 & 11.113 & 2.904 \\
\hline$p$-Value & 0.004 & 0.004 & 0.332 & 0.2 & 0.046 & 0.046 \\
\hline
\end{tabular}

Values are for axes 1 and 2 plotted in the RDA diagram in Fig. 2. 
a

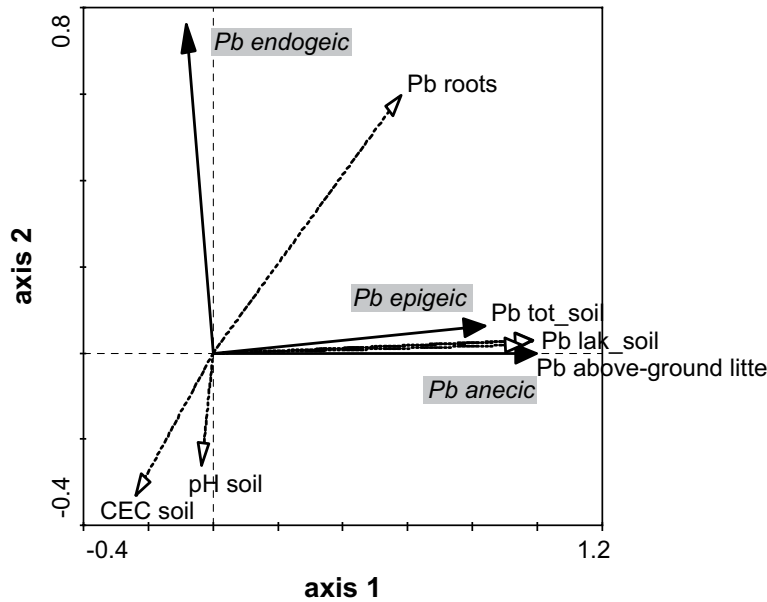

C $\mathrm{Hg}$

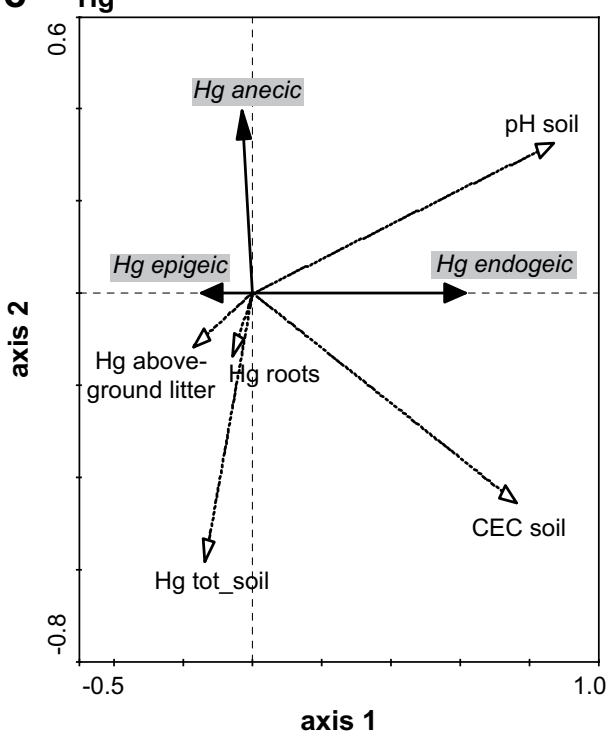

b cd

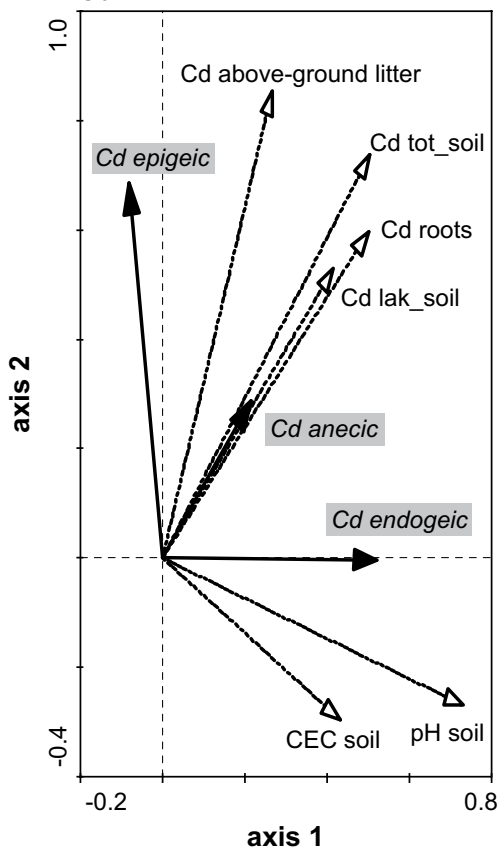

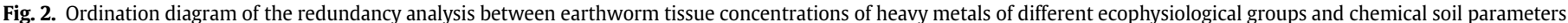
such as $\mathrm{HNO}_{3}$-extractable $\mathrm{HM}$ concentrations in soils, leaf litter, roots, concentrations in Lakanen extracts of soils, pH value and $\mathrm{CEC}$ for the elements (a) Pb, (b) $\mathrm{Cd}$ and (c) $\mathrm{Hg}$.

concentrations in roots were found to be less important. In contrast, $\mathrm{Pb}$ concentrations in endogeic earthworms were not strongly related to $\mathrm{Pb}$ concentrations in soils or above-ground litter but they were found to have high negative correlations to soil $\mathrm{pH}$ and CEC (Fig. 2a).

First and second ordination axes explained only $27.9 \%$ of the total variance within the tissue Cd concentrations in earthworms (Table 5). However, the species-environment relationship was high indicating strong relationships between soil chemical parameters, above-ground litter and roots and tissue $\mathrm{Cd}$ concentrations in earthworms (Table 5). Ordination diagrams demonstrated that tissue $\mathrm{Cd}$ concentrations in anecic earthworms were highly correlated to the $\mathrm{Cd}$ concentrations in soils $\left(\mathrm{HNO}_{3}\right.$ - and Lakanen-extractable) and roots (Fig. 2b). In addition, Cd concentrations in above-ground litter showed a weak but positive relationship with tissue Cd concentrations in epigeic and anecic earthworms. With respect to $\mathrm{Hg}$, redundancy analysis showed that $34.8 \%$ of the total variance within the tissue $\mathrm{Hg}$ concentrations in earthworms was explained by soil chemical parameters, above-ground litter and roots (Table 5). Ordination diagrams revealed that $\mathrm{Hg}$ concentrations in epigeic earthworms were positively correlated to the $\mathrm{Hg}$ concentrations in above-ground litter and the $\mathrm{Hg}$ concentrations in endogeic earthworms showed a positive relationship to the $\mathrm{pH}$ values (Fig. 2c).

The results of the RDA were based on the data set, which included values from all sites (the natural forest sites and the two contaminated sites Gerlafingen and Zuchwil). Eigenvalues of $\mathrm{Pb}$ and $\mathrm{Cd}$ in RDA decrease when excluding the contaminated sites Gerlafingen and Zuchwil from $97 \%$ to $45 \%$ and $21 \%$ to $19 \%$, respectively (data not shown). Thus, the high eigenvalues, especially in the case of $\mathrm{Pb}$, might be influenced by the overall high HM concentrations at both contaminated sites. However, the relationships between soil chemical properties and heavy metal concentrations in earthworms remained the same as described above.

\section{Discussion}

4.1. Heavy metal concentrations in soils, roots and above-ground litter

The $\mathrm{HNO}_{3}$-extractable $\mathrm{Pb}$ concentrations in the top layer of our forest soils (except for the sites at Gerlafingen (in the region of a smelter) and Zuchwil (shooting range)) were within the ranges 
reported for natural forest sites in Finland (Lukkari et al., 2004: 27$49 \mathrm{mg} \mathrm{Pb} \mathrm{kg}{ }^{-1}$ dry soil), in Poland (Rozen, 2006: 0.4-68 mg Pb kg-1 dry soil) and in South Germany (Rahtkens and von der Trenck, 2006: $0.2-280 \mathrm{mg} \mathrm{Pb} \mathrm{kg}^{-1}$ dry soil). The $\mathrm{Pb}$ concentrations in the soils at Gerlafingen and Zuchwil were comparable to the pollution levels in metalliferous mine sites studied by Morgan and Morgan (1998) and Terhivuo et al. (1994). Fourteen forest soils showed enrichment of $\mathrm{Pb}$ exceeding the maximum allowable concentration of $50 \mathrm{mg} \mathrm{Pb} \mathrm{kg}^{-1}$ dry soil as recommended by the Swiss Environmental Legislation (OIS, 1998), indicating that almost half of the natural forest ecosystems were enriched in $\mathrm{Pb}$. This is in accordance with a study by Blaser et al. (2000) reporting that more than $50 \%$ of investigated forest soils similar to ours exhibited a $\mathrm{Pb}$ concentration that could not be explained by in situ weathering of the bedrock. These authors suggested that the high enrichments are most likely due to atmospheric pollution (Blaser et al., 2000). The $\mathrm{HNO}_{3}$-extractable $\mathrm{Cd}$ concentrations were consistent with values from uncontaminated sites (Marino and Morgan, 1999a,b; Pizl and Josens, 1995; Rahtkens and von der Trenck, 2006). Five soils exceeded the guide level for Cd $\left(0.8 \mathrm{mg} \mathrm{kg}^{-1}\right.$ dry soil; OIS, 1998), where four out of the five soils had lithogenic Cd concentrations (sites 1-4; Table 2) and one forest site was near a metal smelter (site 5: Gerlafingen). Mean $\mathrm{HNO}_{3}$-extractable $\mathrm{Hg}$ concentrations in the topsoil were in the same order of magnitude as reported from uncontaminated forest sites (Grigal, 2003; Rahtkens and von der Trenck, 2006) but six out of 27 soils were in the range of those reported from surface organic horizons (0.3-0.4 $\mathrm{mg} \mathrm{kg}^{-1}$ ) in central Europe (Schwesig et al., 1999). Interestingly, most of our forest soils (more than $80 \%$ ) were higher than the natural background $\mathrm{Hg}$ concentrations ( $0.1 \mathrm{mg} \mathrm{kg}^{-1}$ dry soil) as documented by Grigal (2003) indicating $\mathrm{Hg}$ enrichment possibly due to atmospheric pollution.

\subsection{Species-specific heavy metal accumulation in earthworms}

HM tissue concentrations showed large variability among earthworms, which is consistent with values from other studies (Nahmani et al., 2007). The concentrations of Pb in the earthworm tissues were of the same order as those reported from the literature for non-contaminated forest sites (Ma, 2004; Morgan and Morgan, 1990; Spurgeon and Hopkin, 1996). Largest Pb tissue concentrations (1618-11533 $\mathrm{mg} \mathrm{kg}^{-1}$ dry tissue) were found in a forest near a shooting range (at Zuchwil). Differences in Pb within individuals can be explained by differences in the vertical distribution of $\mathrm{Pb}$ within the soil profile or by high, but localized, $\mathrm{Pb}$ concentrations in the topsoil, particularly in shooting ranges as reported by (Astrup et al., 1999; Vyas et al., 2000).

L. rubellus was found to be the most abundant earthworm species in our forest soils and co-existed in 16 out of the 27 forest sites. Concentrations of $\mathrm{Pb}$ in $L$. rubellus were within the ranges reported by other authors for uncontaminated sites (Marino and Morgan, 1999a,b; Terhivuo et al., 1994; Rahtkens and von der Trenck, 2006). The latter authors reported a background level of $0.5-35 \mathrm{mg} \mathrm{kg}^{-1}$ dry tissue in L. rubellus under natural forest situations in southern Germany, which is somewhat lower than our results. Largest $\mathrm{Pb}$ tissue concentrations were found in the epigeic $D$. rubidus (median $426 \mathrm{mg} \mathrm{Pb} \mathrm{kg}^{-1}$ dry tissue) which were within the range of $\mathrm{Pb}$ concentrations reported in A. caliginosa (Terhivuo et al., 1994) and Aporrectodea icteria (Savigny, 1826) (Pizl and Josens, 1995) collected from polluted soils. From laboratory experiments these concentrations might be toxic to $L$. rubellus and $A$. caliginosa where values between 320 and $584 \mathrm{mg} \mathrm{Pb} \mathrm{kg}^{-1}$ in earthworm tissues of $L$. rubellus and A. caliginosa may lead to mortality (Langdon et al., 2005). D. rubidus is known to tolerate low soil pH (Bouché, 1972) and was able to tolerate high $\mathrm{Pb}$ concentrations in the tissues. Whether internal tolerance mechanisms are activated which make the earthworms able to tolerate these high $\mathrm{Pb}$ concentrations in their tissues is not known. There is evidence that species-specific physiological properties of different earthworms such as efficiency of detoxification mechanisms, gut morphology, and numbers of metal-binding ligands (Becquer et al., 2005; Saxe et al., 2001; Spurgeon and Hopkin, 1996) influence the accumulation of HM in earthworm tissues. In the present study, D. rubidus was predominant in the surface soil layers of deciduous forests in the southern part of Switzerland (canton Ticino: sites 21, 22 and 24-27) where soils were very acidic $\left(\mathrm{pH} \mathrm{CaCl}_{2}\right.$ : 3.4-3.8). Data from deposition rates in this region of Switzerland (1990: 43.5 $\mu \mathrm{g} \mathrm{Pb} \mathrm{m}^{-2} \mathrm{~d}^{-1}$; 2000: $11.5 \mu \mathrm{g} \mathrm{Pb} \mathrm{m}^{-2} \mathrm{~d}^{-1}$ ) indicate that these soils were highly enriched with $\mathrm{Pb}$ through atmospheric inputs compared to other regions of Switzerland (FOEFL, 2004). There are indications that concentrations of $\mathrm{Pb}$ were generally greater in epigeic than in endogeic species inhabiting soils contaminated by vehicular emissions (Marino et al., 1992). Pb compounds in earthworms may be transferred to other species at higher trophic levels and may be lethal to earthworm consumers (Hui, 2002; Ireland and Richards, 1977; Ma, 1982, 1989; Vyas et al., 2000). Therefore, with regard to risk assessment of $\mathrm{Pb}$ biomagnification, these forest soils dominated by $D$. rubidus possess a high potential of risk to secondary predators.

Earthworms accumulated less $\mathrm{Cd}$ than $\mathrm{Pb}$, which is in accordance with the literature (Nahmani et al., 2007). The highest tissue concentrations of $\mathrm{Cd}\left(57.1 \mathrm{mg} \mathrm{Cd} \mathrm{kg}^{-1} \mathrm{dw}\right)$ and $\mathrm{Hg}\left(4.9 \mathrm{mg} \mathrm{Hg} \mathrm{kg}^{-1}\right.$ dry wt) were found in the endogeic species 0 . cyaneum which accords with other studies (Dai et al., 2004; Ernst and Frey, 2007; Morgan and Morgan, 1999) reporting that endogeic species feeding mainly on soil efficiently accumulate HM from soil. In contrast, lowest tissue $\mathrm{Cd}$ and $\mathrm{Hg}$ concentrations were determined in L. rubellus (median of $7.31 \mathrm{mg} \mathrm{Cd} \mathrm{kg}^{-1} \mathrm{dw}$ ). L. rubellus, an epigeic species, which occurs mostly in the top layer of the soil, was documented to accumulate low concentrations of HM in general (Marino and Morgan, 1999a,b; Morgan and Morgan, 1992, 1999). In 49 forest soils from south Germany L. rubellus contained Cd tissue concentrations ranging from 0.8 to $10 \mathrm{mg} \mathrm{kg}^{-1}$ dry soil (median: 3.2; Rahtkens and von der Trenck, 2006), values somewhat lower than we found in our study. Assuming a natural background level of 1.7-5.2 $\mathrm{mg} \mathrm{Cd} \mathrm{kg}^{-1}$ dry tissue in L. rubellus (Rahtkens and von der Trenck, 2006) indicates that $L$. rubellus in our forest soils was not strongly enriched. Rozen (2006) reported a Cd tissue concentration of $8.7 \mathrm{mg} \mathrm{kg}^{-1}$ in Dendrobaena octaedra (Savigny, 1826) from unpolluted forest soil, which was within the range for L. rubellus in our study. In contrast, the Cd concentrations in L. rubellus from natural forest sites were considerably lower than in polluted soils (up to $26.3 \mathrm{mg} \mathrm{Cd} \mathrm{kg}^{-1}$ dry tissue) near smelters (Dai et al., 2004).

Concentrations of $\mathrm{Hg}$ in L. rubellus (median of $0.18 \mathrm{mg} \mathrm{Hg} \mathrm{kg}^{-1}$ dry $w \mathrm{t}$ ) were within the range reported by Rahtkens and von der Trenck (2006) for $L$. rubellus of $0.07-0.32 \mathrm{mg} \mathrm{kg}^{-1}$ dry soil (median: 0.18 ) in natural forest sites. These authors reported a background $\mathrm{Hg}$ level of $0.12-0.3 \mathrm{mg} \mathrm{Hg} \mathrm{kg}^{-1}$ dry tissue. Talmage and Walton (1993) reported $\mathrm{Hg}$ tissue concentrations averaging $0.11 \mathrm{mg} \mathrm{Hg} \mathrm{kg}^{-1}$ fresh wt in non-identified earthworms obtained from natural forest sites, which were somewhat lower (assuming a water content of $85 \%$ in earthworms) than we found in our study. Burton et al. (2006) reported $\mathrm{Hg}$ concentrations up to $0.25 \mathrm{mg} \mathrm{Hg} \mathrm{kg}^{-1}$ dry wt in Eisenia fetida (Savigny, 1826) after $28 \mathrm{~d}$ of exposure incubated in a soil with background $\mathrm{Hg}$ concentrations $\left(0.085 \mathrm{mg} \mathrm{kg}^{-1}\right)$. When the soil was slightly contaminated $\left(0.156 \mathrm{mg} \mathrm{Hg} \mathrm{kg}^{-1}\right.$ dry soil) the $\mathrm{Hg}$ tissue concentrations increased to $0.35 \mathrm{mg} \mathrm{Hg} \mathrm{kg}^{-1}$ dry tissue and in a soil with a intermediate $\mathrm{Hg}$ soil contamination $\left(2.825 \mathrm{mg} \mathrm{kg}^{-1}\right.$ soil $)$ the $\mathrm{Hg}$ concentrations in tissues were comparable to that found in $O$. cyaneum. The endogeic $O$. cyaneum could tolerate $\mathrm{Hg}$ concentrations in the tissues up to $24 \mathrm{mg} \mathrm{kg}^{-1}$ dry wt with no reduction in growth during a 35-day feeding experiment (Ernst and Frey, 2007) 
which were considerably higher than the $\mathrm{Hg}$ concentrations in O. cyaneum found under field conditions in the present study. The anecic $L$. terrestris, however, was a less efficient accumulator of $\mathrm{Hg}$ from soil, reaching $6.5 \mathrm{mg} \mathrm{Hg} \mathrm{kg}^{-1}$ dry tissue (Ernst and Frey, 2007) but this species was able to take up $\mathrm{Hg}$ from different food sources (leaf litter, roots and soil).

\subsection{Bioconcentration factors of $\mathrm{Cd}, \mathrm{Hg}$ and $\mathrm{Pb}$}

Highest bioconcentration factors (CF) for the route from soil to earthworms were found for $\mathrm{Cd}$ and lowest for $\mathrm{Pb}$, which is in accordance with other studies (Hsu et al., 2006; Ireland, 1983; Pizl and Josens, 1995). Regarding Cd, the mean concentration factors ranged from 11 to 121 , which are in agreement with those of Ireland (1983), Ma (1982) and Pizl and Josens (1995). Concentration factors for $\mathrm{Pb}$ are generally reported to be lower than 1 (Ireland, 1983; Ma, 1982; Pizl and Josens, 1995). The solubility of $\mathrm{Pb}$ in soil is important for bioaccumulation by earthworms as the main pathways for chemical absorption are the skin (for soluble elements), gut transit and digestion (Weltje, 1998). Cadmium tends to be more mobile in soils and therefore more available to earthworms and roots than many other $\mathrm{HM}$, including $\mathrm{Pb}$ (Ma, 2004) and $\mathrm{Hg}$ (Grigal, 2003). Bioconcentration factors for $\mathrm{Hg}$ were in the range of 1-15 depending on the earthworm species. CFs in endogeic species such as $A$. rosea and $O$. cyaneum were found to be very high, reaching a value of 15. Ernst and Frey (2007) reported lower CFs for the transfer of $\mathrm{Hg}$ from mercury-spiked soil to earthworms, averaging 1.0 for L. terrestris and 2.3 for 0 . cyaneum in a short-term (35 days) microcosm experiment. Similarly, lower CFs (between 0.4 and 4.7) were documented for $E$. fetida and $L$. terrestris in mercurycontaminated soils (Bull et al., 1977; Burton et al., 2006; Edwards et al., 1998; Hinton and Veiga, 2002).

\subsection{Relationships between heavy metal tissue concentrations and environmental variables}

Redundancy analysis (RDA) showed that the most important parameters influencing the accumulation of $\mathrm{Cd}, \mathrm{Hg}$ and $\mathrm{Pb}$ in earthworms were the HM concentrations in the different food sources (soil, above-ground litter and roots) and the chemical soil parameters ( $\mathrm{pH}$ and $\mathrm{CEC}$ ). Both epigeic and anecic earthworms showed a strong relationship between $\mathrm{HM}(\mathrm{Pb}, \mathrm{Cd}$ and $\mathrm{Hg}$ ) tissue concentrations and concentrations in above-ground litter and roots, whereas HM tissue concentrations in endogeic earthworms correlated well with the $\mathrm{HNO}_{3}$-extractable $\mathrm{HM}$ concentrations in soils. These findings support other studies (Dai et al., 2004; Ireland, 1983; Morgan and Morgan, 1992, 1999; van Vliet et al., 2005) in that species differences in total metal concentrations largely reflect differences in food selectivity and niche separation.

While endogeic earthworms feed mainly on soil variously contaminated with metal-bearing mineral phases (Curry and Schmidt, 2007; Lee, 1985; Neilson and Boag, 2003), the concentrations in their tissues were affected largely by the bioavailable fraction in soils. In fact, this fraction was negatively related to soil $\mathrm{pH}$ and CEC as shown by Ma (2004), Morgan and Morgan (1988), and Weltje (1998). Our results show that internal metal concentrations are highly correlated with $\mathrm{HNO}_{3}$-extractable metal concentrations in soil, as observed in several other studies (Becquer et al., 2005; Dai et al., 2004; Hobbelen et al., 2004; Marinussen et al., 1997).

RDA showed low eigenvalues regarding $\mathrm{Hg}$ (0.35) compared to $\mathrm{Pb}(0.97)$ indicating that the factors, which influence the accumulation of $\mathrm{Hg}$ in earthworms were more complex. We do not know whether the eigenvalues in the RDA for $\mathrm{Hg}$ would increase if the tissue-methyl-Hg concentrations were included. Unfortunately, methyl-Hg within earthworms, which can be important in field situations, was not taken into account. Several studies have shown that $\mathrm{MeHg}$ is in general the most bioavailable form of $\mathrm{Hg}$ (Mason et al., 2000), including that pertaining to earthworms (Hinton and Veiga, 2002). Tissue-methyl-Hg determination does not allow discrimination between methyl-Hg accumulated from soil and $\mathrm{Hg}$ methylated within the organisms (Gnamus et al., 2000). Methylation of inorganic $\mathrm{Hg}$ within an earthworm can occur and was recently shown by Hinton and Veiga (2002) in the intestinal tract of E. fetida. Because of its tendency to adsorb on organic soil components (Hakanson et al., 1990) and its high solubility (Mason et al., 1994), it accumulates in invertebrates and is magnified in organisms of the upper food chain (Talmage and Walton, 1993). We suggest that this issue needs to be addressed urgently to allow the development of ecologically relevant risk assessment procedures for mercury-contaminated soils.

\section{Conclusions}

Our results have extended and confirmed earlier observations (Morgan and Morgan, 1993; Morgan et al., 1986) that speciesspecific accumulation patterns of non-essential HMs in earthworms occur. In contrast, this study is one of the very few that have shown bioaccumulation of mercury in different ecophysiological groups of earthworms in forest sites under natural conditions. The distributions of $\mathrm{Cd}, \mathrm{Hg}$ and $\mathrm{Pb}$ in the varying food sources influenced their accumulation in the different ecophysiological categories of earthworms, reflecting the differences in food selectivity and niche separation. Attention should therefore be given to the ecological categories of earthworms and the HM concentrations in the most relevant food sources of earthworms when evaluating the effects of $\mathrm{Hg}$ and other non-essential $\mathrm{HM}$ on bioaccumulation in earthworms. These issues need to be addressed further to provide more accurate estimates of the ecological risks posed by $\mathrm{Hg}, \mathrm{Cd}$ and $\mathrm{Pb}$ in forest ecosystems.

\section{Acknowledgements}

We are grateful to Peter Blaser and Ivano Brunner for helpful discussions. We also thank Janka Bollenbach and Daniele Pezzotta of the WSL Central Laboratory for heavy metal analysis. Financial support was provided by the Federal Office for the Environment (810.3189.004 and 810.361.103/145).

\section{References}

Abdul Rida, A.M.M., Bouché, M.B., 1997. Heavy metal linkages with mineral, organic and living soil compartments. Soil Biology and Biochemistry 29, 649-655.

Astrup, T., Boddum, J.K., Christensen, T.H., 1999. Lead distribution and mobility in a soil embankment used as a bullet stop at a shooting range. Journal of Soil Contamination 8, 653-665.

Becquer, T., Dai, J., Quantin, C., Lavelle, P., 2005. Sources of bioavailable trace metals for earthworms from a $\mathrm{Zn}-, \mathrm{Pb}$ - and Cd-contaminated soil. Soil Biology and Biochemistry 37, 1564-1568.

Beyer, W.N., Hensler, G., Moore, J., 1987. Relation of pH and other soil variables to concentrations of $\mathrm{Pb}, \mathrm{Cu}, \mathrm{Zn}, \mathrm{Cd}$, and $\mathrm{Se}$ in earthworms. Pedobiologia 30, 167-172.

Blaser, P., Zimmermann, S., Luster, J., Shotyk, W., 2000. Critical examination of trace element enrichments and depletions in soils: $\mathrm{As}, \mathrm{Cr}, \mathrm{Cu}, \mathrm{Ni}, \mathrm{Pb}$, and $\mathrm{Zn}$ in Swiss forest soils. Science of the Total Environment 249, 257-280.

Blaser, P., Zimmermann, S., Luster, J., Walthert, L., Lüscher, P., 2005. Waldböden der Schweiz, Band 2. Regionen Alpen und Alpensüdseite. Swiss Federal Research Institute WSL, Hep Verlag, Bern, Switzerland, 920 pp.

Bouché, M.B., 1972. Lombriciens de France: écologie et systématique. In: Annals de Zoologie - écologie animal. Institut National de la Recherche Agronomique, Paris.

Bull, K.R., Roberts, R.D., Inskip, M.J., Goodman, G.T., 1977. Mercury concentrations in soil, grass, earthworms and small mammals near an industrial emission source. Environmental Pollution 12, 135-140.

Burton, D.T., Turley, S.D., Fisher, D.J., Green, D.J., Shedd, T.R., 2006. Bioaccumulation of total mercury and monomethylmercury in the earthworm Eisenia fetida. Water, Air, and Soil Pollution 170, 37-54.

Carpené, E., Andreani, G., Monari, M., Castellani, G., Isani, G., 2006. Distribution of $\mathrm{Cd}, \mathrm{Zn}, \mathrm{Cu}$ and Fe among selected tissues of the earthworm (Allolobophora 
caliginosa) and Eurasian woodcock (Scolopax rusticola). Science of the Total Environment 363, 126-135.

Curry, J.P., Schmidt, O., 2007. The feeding ecology of earthworms - a review. Pedobiologia 50, 463-477.

Dahmani-Muller, H., van Oort, F., Gelie, B., Balabane, M., 2000. Strategies of heavy metal uptake by three plant species growing near a smelter. Environmental Pollution 109, 231-238.

Dai, J., Becquer, T., Rouiller, J.H., Reversata, G., Bernhard-Reversata, F., Nahmania, J., Lavelle, P., 2004. Heavy metal accumulation by two earthworm species and its relationship to total and DTPA-extractable metals in soils. Soil Biology and Biochemistry 36, 91-98.

Driscoll, C.T., Han, Y.J., Chen, C.Y., Evers, D.C., Lambert, K.F., Holsen, T.M., Kamman, N. C., Munson, R.K., 2007. Mercury contamination in forest and freshwater ecosystems in the Northeastern United States. Bioscience 57, 17-28.

De Vries, W., Schütze, G., Lots, S., Meili, M., Römkens, P., Terytze, K., Scholz, K., Farret, R., Jakubowski, M., 2002. Critical limits for cadmium, lead and mercury related to ecotoxicological effects on soil organisms, aquatic organisms, plants, animals and humans. Background document for the "Expert meeting on critical limits for heavy metals and methods for their application", Berlin 2-4 December 2002, held under the UNECE Convention on long range transboundary air pollution.

Edwards, C.A., Lofty, J.R., 1977. Biology of Earthworms, second ed. Bookworm Publisher Company, London.

Edwards, S.C., MacLeod, C.L., Lester, J.N., 1998. The bioavailability of copper and mercury to the common nettle (Urtica dioica) and the earthworm Eisenia fetida from contaminated dredge spoil. Water, Air and Soil Pollution 102, 75-90.

Emmerling, C., Krause, K., Schröder, D., 1997. The use of earthworms in monitoring soil pollution by heavy metals. Zeitschrift für Pflanzenernährung und Bodenkunde 160, 33-39.

Ernst, G., Frey, B., 2007. The effect of feeding behaviour on $\mathrm{Hg}$ accumulation in the ecophysiologically different earthworms Lumbricus terrestris and Octolaseon cyaneum: a microcosm experiment. Soil Biology and Biochemistry 39, 386-390.

Ettler, V., Vanek, A., Mihaljevic, M., Bezdicka, P., 2005. Contrasting lead speciation in forest and tilled soils heavily polluted by lead metallurgy. Chemosphere 58, 1449-1459.

FOEFL, 2004. Deposition of Air Pollutants in Switzerland. Umweltmaterialien Nr. 180. Swiss Federal Office of Environment, Forests and Landscape, Bern, Switzerland.

Gnamus, A., Byrne, A.R., Horvat, M., 2000. Mercury in the soil-plant-deer-predator food chain of a temperate forest in Slovenia. Environmental Science and Technology 34, 3337-3345.

Green, R.N., Trowbridge, R.L., Klinka, K., 1993. Towards a taxonomic classification of humus forms. Forest Science Monograph 29, 1-49.

Grigal, D.F., 2003. Mercury sequestration in forests and peatlands: a review. Journal of Environmental Quality 32, 393-405.

Hakanson, L., Nilsson, A., Andersson, T., 1990. Mercury in Swedish mor layers linkages to mercury deposition and sources of emission. Water, Air and Soil Pollution 50, 155-174.

Hinton, J.J., Veiga, M.M., 2002. Earthworms as bioindicators of mercury pollution from mining and other industrial activities. Geochemistry: Exploration, Environment, Analysis 2, 269-274.

Hobbelen, P.H.F., Koolhaas, J.E., van Gestel, C.A.M., 2004. Risk assessment of heavy metal pollution for detritivores in floodplain soils in the Biesbosch, The Netherlands, taking bioavailability into account. Environmental Pollution 129, 409-419.

Hu, A., Häni, H., 1983. Dissolving heavy metals from soils with acids in order to approximate total element content. Zeitschrift für Pflanzenernährung und Bodenkunde 146, 481-493.

Hui, C.A., 2002. Lead distribution throughout soil, flora, and an invertebrate at a wetland skeet range. Journal of Toxicology and Environmental Health 65, 1093-1107.

Hsu, M.J., Selvaraj, K., Agoramoorthy, G., 2006. Taiwan's industrial heavy metal pollution threatens terrestrial biota. Environmental Pollution 143, 327-334.

Ireland, M.P., Richards, K.S., 1977. The occurrence and localisation of heavy metals and glycogen in earthworms Lumbricus rubellus and Dendrobaena rubida from a heavy metal site. Histochemistry $51,153-166$.

Ireland, M.P., 1983. Heavy metal uptake and tissue distribution in earthworms. In: Satchell, J.E. (Ed.), Earthworm Ecology. Chapman and Hall, London, pp. 247-265.

Klaminder, J., Bindler, R., Emteryd, O., Renberg, I., 2005. Uptake and recycling of lead by boreal forest plants: quantitative estimates from a site in northern Sweden. Geochimica et Cosmochimica Acta 69, 2485-2496.

Klok, C., Van der Hout, A., Bodt, J., 2006. Population growth and development of the earthworm Lumbricus rubellus in a polluted field soil: possible consequences for the godwit (Limosa limosa). Environmental Toxicology and Chemistry 25, 213-219.

Langdon, C.J., Piearce, T.G., Meharg, A.A., Semple, K.T., 2001. Resistance to copper toxicity in populations of the earthworms Lumbricus rubellus and Dendrodrilus rubidus from contaminated mine wastes. Environmental Toxicology and Chemistry 20, 2336-2341.

Langdon, C.J., Hodson, M.E., Arnold, R.E., Black, S., 2005. Survival, Pb-uptake and behaviour of three species of earthworm in Pb treated soils determined using an OECD-style toxicity test and a soil avoidance test. Environmental Pollution 138, 368-375.

Lakanen, E., Ervio, R.A., 1971. A comparison of eight extractants for the determination of plant available micronutrients in soils. Acta Agriculturae Fennica $123,223-232$
Lee, K.E., 1985. Earthworms - Their Ecology and Relationships with Soils and Landuse. Academic Press, New York, Sydney, London.

Leps, L., Smilauer, P., 2003. Multivariate Analysis of Ecological Data Using CANOCO. Cambridge University Press, Cambridge, UK.

Lukkari, T., Taavitsainen, M., Väisänen, A., Haimi, J., 2004. Effects of heavy metals on earthworms along contamination gradients in organic rich soils. Ecotoxicology and Environmental Safety 59, 340-348.

Ma, W.-C., 1982. The influence of soil properties and worm-related factors on the concentration of heavy metals in earthworms. Pedobiologia 24,109-119.

Ma, W.-C., 1989. Effect of soil pollution with metallic lead pellets on lead bioaccumulation and organ/body weight alterations in small mammals. Archives of Environmental Contamination and Toxicology 18, 617-622.

Ma, W.-C., 2004. Estimating heavy metal accumulation in oligochaete earthworms: a meta-analysis of field data. Bulletin of Environmental Contamination and Toxicology 72, 663-670.

Ma, W.-C., Talmage, S.S., 2001. Insectivora. In: Shore, R.F., Rattner, B.A. (Eds.) Ecotoxicology of Wild Mammals. Wiley, Chichester, pp. 123-158.

Marinussen, M.P.J.C., Van der Zee, S.E.A.T.M., de Haan, A.M., 1997. Cu accumulation by Lumbricus rubellus under laboratory conditions compared with accumulation under field conditions. Ecotoxicology and Environmental Safety 36, 17-26.

Marino, F., Ligero, A., Diaz Cosin, D.J., 1992. Heavy metals and earthworms on the border of a road next to Santiago (Galicia, Northwest of Spain). Initial results. Soil Biology and Biochemistry 24, 1705-1709.

Marino, F., Morgan, A.J., 1999a. The time-course of metal (Ca, Cd, Cu, Pb, Zn) accumulation from a contaminated soil by three populations of the earthworm, Lumbricus rubellus. Applied Soil Ecology 12, 169-177.

Marino, F., Morgan, A.J., 1999b. Equilibrated body metal concentrations in laboratory exposed earthworms: can they be used to screen candidate metal-adapted populations? Applied Soil Ecology 12, 179-189.

Mason, R.P., Fitzgerald, W.F., Morel, F.M.M., 1994. The biogeochemical cycling of elemental mercury: anthropogenic influences. Geochimica et Cosmochimica Acta 58, 3191-3198.

Mason, R.P., Laporte, J.-M., Andres, S., 2000. Factors controlling the bioaccumulation of mercury, methylmercury, arsenic, selenium, and cadmium by freshwater invertebrates and fish. Archives of Environmental Contamination and Toxicology 38, 283-297.

Morgan, J.E., Morgan, A.J., 1988. Earthworms as biological monitors of cadmium, copper, lead and zinc in metalliferous soils. Environmental Pollution 54,123-138.

Morgan, J.E., Morgan, A.J., 1990. The distribution of cadmium, copper, lead, zinc and calcium in the tissues of the earthworm Lumbricus rubellus sampled from one uncontaminated and four polluted soils. Oecologia 84, 559-566.

Morgan, A.J., Morgan, J.E., 1992. The accumulation and intracellular compartmentation of cadmium, lead, zinc and calcium in two earthworm species (Dendrobaena rubida and Lumbricus rubellus) living in highly contaminated soil. Histochemistry 75, 269-285.

Morgan, J.E., Morgan, A.J., 1993. Seasonal changes in the tissue-metal (Cd, Zn, and $\mathrm{Pb}$ ) concentrations in two ecophysiologically dissimilar earthworm species: Pollution monitoring implications. Environmental Pollution 82, 1-7.

Morgan, J.E., Morgan, A.J., 1998. The distribution and intracellular compartmentation of metals in the endogeic earthworm Aporrectodea caliginosa sampled from an unpolluted and a metal-contaminated site. Environmental Pollution 99, 167-175.

Morgan, J.E., Morgan, A.J., 1999. The accumulation of metals (Cd, Cu, Pb, Zn and $\mathrm{Ca}$ ) by two ecologically contrasting earthworm species (Lumbricus rubellus and Aporrectodea caliginosa): implications for ecotoxicological testing. Applied Soil Ecology 13, 9-20.

Morgan, J.A., Morris, B., James, N., Morgan, J.E., Leyshon, K., 1986. Heavy metals in terrestrial macroinvertebrates: species differences within and between trophic levels. Chemistry and Ecology 2, 319-334.

Nahmani, J., Hodson, M.E., Black, S., 2007. A review of studies performed to assess metal uptake by earthworms. Environmental Pollution 145, 402-424.

Neilson, R., Boag, B., 2003. Feeding preferences of some earthworm species common to upland pastures in Scotland. Pedobiologia 47, 1-8.

OIS, 1998. Swiss Ordinance relating to Impacts on the Soil: 1stJuly 1998. SR 814.12 Switzerland.

Pizl, V., Josens, G., 1995. Earthworm communities along a gradient of urbanization. Environmental Pollution 90, 7-14.

Rahtkens, K., von der Trenck, K.T., 2006. Schwermetalle in Regenwürmern Baden-Württembergs. Teil 1: Metallgehalte in Regenwürmern von WaldDauerbeobachtungsflächen. Umweltwissenschaften und Schadstoff-forschung $18,164-174$.

Raw, F., 1959. Estimating earthworm populations by using formalin. Nature 184, $1661-1662$.

Rozen, A., 2006. Effect of cadmium on life-history parameters in Dendrobaena octaedra (Lumbricidae: Oligochaeta) populations originating from forests differently polluted with heavy metals. Soil Biology and Biochemistry 38, 489-503.

Saxe, J.K., Impellitteri, C.A., Peijnenburg, W.J.G.M., Allen, H.E., 2001. Novel model describing trace metal concentrations in the Earthworm Eisenia Andrei. Environmental Science and Technology 35, 4522-4529.

Schwesig, D., Ilgen, G., Matzner, E., 1999. Mercury and methylmercury in upland and wetland acid forest soils of a watershed in NE-Bavaria, Germany. Water, Air and Soil Pollution 113, 141-154.

Schwesig, D., Matzner, E., 2000. Pools and fluxes of mercury and methylmercury in two forested catchments in Germany. Science of the Total Environment 260, 213-223.

Sims, R.W., Gerard, B.M., 1985. Earthworms. The Linnean Society of London. 
Spurgeon, D.J., Hopkin, S.P., 1996. The effects of metal contamination on earthworm populations around a smelting works - quantifying species effects. Applied Soil Ecology 4, 147-160.

Spurgeon, D.J., Weeks, J.M., Van Gestel, C.A.M., 2003. A summary of eleven years progress in earthworm ecotoxicology. Pedobiologia 47, 588-606.

Steinnes, E., Åberg, G., Hjelmseth, H., 2005. Atmospheric deposition of lead in Norway: spatial and temporal variation in isotopic composition. Science of the Total Environment 336, 105-117.

Talmage, S.S., Walton, B.T., 1993. Food chain transfer and potential renal toxicity of mercury to small mammals at a contaminated terrestrial field site. Ecotoxicology (Historical Archive) 2, 243-265.

Terhivuo, J., Pankakoski, E., Hyvarinen, H., Koivisto, 1994. Pb uptake by ecologically dissimilar earthworm (Lumbricidae) species near a lead smelter in South Finland. Environmental Pollution 85, 87-96.

Ter Braak, C.J.F., Smilauer, P., 2002. CANOCO Reference Manuel and CanoDraw for Windows User's Guide, Software for Canonical Community Ordination (version 4.5). Biometris, Wageningen and Ceske Budejovice, 2002.
UNECE, Aarhus Protocol, 1998. Protocol of the 1979 Convention of Long-range Transboundary Air Pollution on Heavy Metals. UNECE.

van Vliet, P.C.J., van der Zee, S.E.A.T.M., Ma, W.-C., 2005. Heavy metal concentrations in soil and earthworms in a floodplain grassland. Environmental Pollution 138, 505-516.

Vyas, N.B., Spann, J.W., Heinz, G.H., Beyer, W.N., Jaquette, J.A., Mengelkoch, J.M., 2000. Lead poisoning of passerines at a trap and skeet range. Environmental Pollution 107, 159-166.

Walthert, L., Zimmermann, S., Blaser, P., Luster, J., Lüscher, P., 2004. Waldböden der Schweiz, Band 1, Grundlagen und Region Jura. Swiss Federal Research Institute WSL, Hep Verlag, Bern, Switzerland, 761 pp.

Weltje, L., 1998. Mixture toxicity and tissue interactions of $\mathrm{Cd}, \mathrm{Cu}, \mathrm{Pb}$ and $\mathrm{Zn}$ in earthworms (Oligochaeta) in laboratory and field soils: a critical evaluation of data. Chemosphere 36, 2643-2660.

Zimmermann, S., Luster, J., Blaser, P., Walthert, L., Lüscher, P., 2006. Waldböden der Schweiz, Band 3, Regionen Mittelland und Voralpen. Swiss Federal Research Institute WSL, Hep Verlag, Bern, Switzerland, 848 pp. 